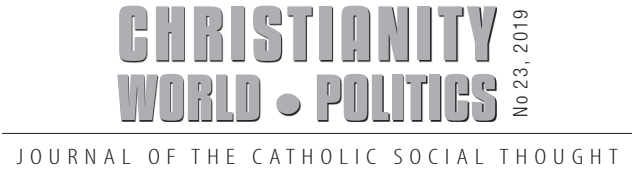

Miroljub Jevtić

University of Belgrade, Serbia

\title{
25 Years of Politology of Religion
}

\begin{abstract}
The increasing influence of religion in politics - a fact which was suddenly noticed after the Iranian Islamic revolution, the role of religion in the downfall of the Warsaw Pact and socialist regimes in Eastern Europe, the resurgence of Hinduism by using the Bharatia Janata Party in India, the increasing importance of Judaism as a political ideology in Israel along with other examples from different religions, all together represented a challenge for political science. At the time, political science disciplines were not able to offer a solution for these questions. As a result, a specific political science discipline emerged, namely the Politology of Religion. This is a specific scientific discipline because of its specific research subject, separating it from other disciplines. Therefore, Politology of religion is both a general and a specific political science discipline. It is general because without its findings the education of a political scientist is not possible. On the other side, Politology of religion is a specific discipline due to its research of political science themes, in the context of religion. This discipline was firstly introduced as a course in the Department of Political Science of the University of Belgrade, in the school year 1993/1994. So far, hundreds of undergraduate political science students attended this course. Meanwhile, both Master and Specialist studies in Politology of Religion were developed. There is a Doctoral course as well. Therefore, the Department of Political Science of the University of Belgrade, educates politologists of religion from the undergraduate level, to the $\mathrm{PhD}$ level. The peak development of this discipline was, however, the first in the world publication of a journal in English dedicated to politics and religion - The Politics and Religion Journal (PRJ). PRJ gets its most valuable recognition from its authors, who come from all over the world. As such, PRJ is one of the most-multicultural social science Journal in the world.
\end{abstract}

Keywords: religion, politics, research, science, politology of religion

When it comes to institutions which are dealing with Political Science, we can see that they are rather young, particularly when it comes to the differentiation of Political Science as a specific scientific discipline with a specific field of study, in contrast with other social sciences. For example, the Academy of Moral and 
Political Sciences in Paris was founded in 1795. It consisted of departments of philosophy, ethics, political economy, law and history. However, there was no specific department of Political Science, as all above mentioned sciences were considered as political and there was no such thing as a distinctive Political Science at that time. Therefore, the Academy which was founded for the purpose of studying Political Science, claimed that there is no such thing. The first school in the world which was dedicated particularly to Political Science was L,ecole libre des sciences politiques. In 1945 this school became the Institut d,etudes politiques. Nowadays, there are 10 similar institutes in France. The last one was founded in 2013 in Saint Germain en Lay, only 20km away from Paris. This tells us a story about the development of departments of Political Sciences in this country.

It is quite similar in London. The London School of Economics and Political Sciences (LSE) was founded in 1895. It is also important to mention that this is the full name of this school, despite the fact that many refer to it as the London School of Economics. Since 1872 we can see a great development of Political Science around the globe, resulting in a fact that today, we almost cannot find a University in the world without a Department for political science.

If we first take a look at the curriculums and programs of these institutions, we can see that their main research focuses on the analysis of political theory, political order, comparative politics, political organizations, international relations, internal politics etc. All of these disciplines have a secular dimension. This is quite normal, as modern science is materialistic and based on facts, with a goal to be serious and precise. When it comes to religion, we can say that political science ever since its formation was very anti-religiously oriented, under the influence of French Enlightenment, which claimed that religion will disappear. Due to that fact, Political Science did not take religion into account and did not consider it as a source of political behavior and politics in general. On the other hand, when it dealt with religion through above mentioned disciplines, it was always through the understanding that religion will soon disappear.

This can be best seen in the work of Peter Berger, who said that "it is realistic to expect that believers in the XXI century can be only found in small sects, gathered with a goal to resist the world secular culture". It is almost impossible to understand that someone with such great authority can say something like this, only one year before the creation of the Organization of Islamic Cooperation, the second largest Inter-governmental organization in the world, just after the UN. 
Even though science should avoid using value statements, we will break this rule and say that Berger's statement was stupid. Later he said that he was wrong and by that he made an indirect apology, saying that the world today "is fiercely religious as it has always been, and in some parts even more than before".

As this is a work of the politology of religion, someone might ask why are we quoting a sociologist. We do so because the sociologist understood the significance of religion much before the politologists, giving birth to a special discipline: the sociology of religion. However, when they formed the sociology of religion, they did not pay much attention to it, unlike other social disciplines. This is because they all believed that religion will soon disappear as well, as Berger claimed. They formed the ISA (International Sociological Association) in 1949, with support from UNESCO. Research Committee 22 for the Sociology of Religion was formed 10 years later, in 1959.

At the same time, in 1949, the IPSA was formed (International Political Science Association), again with support from UNESCO. The headquarters of this organization is at the University of Concordia, Canada. Contrary to sociologists, politologists showed a higher level of rigidity towards religion. They failed to see that religion is the foundation of many modern states, such as Pakistan, formed in 1947, or Israel. Therefore, Pakistan is proof that religion is a fact of the future, not of the past. On the other hand, political science has the state as its main topic of research. Even though the state of Pakistan, formed in 1947, is two years older than the IPSA, it was not valid proof for it to be acknowledged that religion is the primary source of politics, same as a nation is. It is particularly important to emphasize the fact that Pakistan openly stated that they want to create a state for Muslims. Hence the name Pakistan, as "paks" in Urdu language means "state of religiously clean". Only after decades and important political events, such as the role of the Vatican in the dissolution of the Warsaw Pact, the Iranian Islamic revolution in 1979 etc., that it became obvious that religion was the primary source of political behavior. Nevertheless, Political Science did not react. Only after 50 years, the IPSA founded RC 43 for Religion and Politics in 1999.

The situation with the most important political science association in Europe European Consortium for Political Research (ECPR), is similar. This organization was formed in 1970. Its standing group for Religion and Politics was formed in 2006. This is not hard to explain. Western political science, which was uncritically labeled as liberal, was very dogmatic and rigid when it comes to religion as 
a source of politics. At the same time, behind the Iron curtain, science was based on dogmatic Marxism.

A great example of this is a research of Steven Kettell, member of our Editorial board. In 2012 he published his analysis 11 years after 9/11 [Kettell 2012]. This event, the attack of Al Qaeda on the World Trade Center in New York and the Pentagon building, was labeled as a result of Islamic extremism. Everyone agreed that religion served as a source of political action which changed the world. 11 years after, Kettle's analysis showed that 20 leading political science journals published 7254 articles. And that only 184 of them, $2,54 \%$, has religion as a primary or secondary research subject. More precisely, 97 articles has religion as a primary subject of research, while 87 articles has religion as a secondary source of analysis [Kettell 2012].

More or less, we dealt with Anglophone sources so far. Let's take a look how things are doing in other big cultures and states where political science is developed. For example, if we search "politologie des religion" on the online catalog of the French National Library, we can see that there is not a single entry containing this term. On the other hand, the library catalogue of the Institute d'etudes politiques has only one source under the same search: Politics and Religion Journal, which has a parallel French title "Politologie des religion". This Journal is published by the Center for Study of Religion and Religious Tolerance, from Belgrade. So, even though there is a French term "politologie des religions", coined just like "sociology des religions", French authors did not publish a single article so far under this term. If we search Google using this term, we can get a result that "L'Observatoire du Religieux was founded in 1992", within the research project led by Prof. Bruno Etienne, affiliated with "l'Institut d'études politiques and a former member of l'Institut Universitaire de France". As a young group, they managed to become a distinguished organization ,'within sociologie and politologie des religions". This is the only time when the French used this concept. We repeat however, that this young group did not write a single book or scientific article using the term "politologie des religion". But, in the library of "l'Institut d'études politiques" there is an article, wrote by the author of this article. It has almost the identical title as the title of this conference. This is an article published in the Indian Journal of Political Science [Vol. LXX, No. 2, 2009, pp. 409-418]. This article is now 9 years old.

If you search the online catalogue of the Library of Congress, the world's largest library, with the keywords "politologie des religions", you will get only one result: 
the above mentioned Politics and Religion Journal. So instead of a French journal, it is a Serbian journal promoting French culture in the USA. If you search the term politology of religion, the only result is a monograph titled Religion and Power-Essays on Politology of Religion [Jevtić 2008]. Politology of religion is only developed in the German speaking countries. Germans coined the term religionspolitologie and founded the "Institut für Religionspolitologiein" in the city of Duisburg. Unfortunately, according to internet sources, this institute is no longer active. Despite this fact, it is important to mention the moto of this Institute: "One who does not understand religion, cannot understand politics", which is very true. It also says that Germans did not understand politics before, as they did not consider religion as a political factor. Moreover, if they understand what religion means for politics, they will not accept to have Muslims immigrants and have no idea what to do with them now. Similarly, the Germans are, partly, responsible for the Armenian genocide, as they supported the Ottoman Empire without thinking about what will remain when such a big state collapses, creating modern Turkey as a religiously homogeneous country. With numerous Christian minorities, Turkey today would have looked very different from what it looks like now, with a different political situation.

According to the above mentioned facts, it is important to say that Politology of religion as a specific political science discipline, was founded at the Department of Political Science, University of Belgrade, in the school year 1993/94. This is the first time in history, that this discipline has become part of the curriculum of Political Science. It is a general fact that, according to the sociology of knowledge, a science is not fully developed until it becomes a part of a University curriculum. As we can see, it happened for the first time at the Department of Political Science in Belgrade. It is very important to say that this process did not go without challenges. Just like political scientists in the world, political scientists in Belgrade did not see religion as important for politics. There was a huge opposition against this course of study. It is the same today. Politology of religion is a core course in the Political science department, while in International relations (IR), Journalism and Social Work departments, they had to wait for 23 years to accept this course as important for the education of a Political Scientist. Only after accreditation in 2015, Politology of Religion was accepted as an elective course in these three departments, but only as an elective, not as a core course. This is particularly important for the IR department, where students in their final year can choose between two modules: International politics and European integration. My colleagues who teach European integration find that Politology of religion is not necessary 
for their students. Not even as an elective course. Even in a situation where the problem of Muslim integration caused French authorities to forbid prayers in the streets, teachers in this module claim that Politology of religion is not needed. However, it is important to see that Politology of religion is now an elective course in two and a half departments and therefore, shows a significant progress in the understanding of this topic.

Despite all the challenges, Politology of religion managed to create significant success and development at the Faculty of Political Sciences in Belgrade. In the beginning, there was a two years specialist program in Politological studies of religion. Since 2015, they are transformed into Master studies in Politological studies of religion. At the same time, one can defend a $\mathrm{PhD}$ thesis in the Doctoral studies and attend lectures. Therefore, Politology of religion is fully developed in the Department of Political Sciences. All three levels of higher education give the opportunity for political-religious education for students.

In the last 25 years, over 1000 students attended lectures in bachelor studies. There are numerous master and several $\mathrm{PhD}$ dissertations. At this moment, there are 13 students in the Master studies and 7 of them in Doctoral studies.

The fact that Politology of religion is born in Belgrade is an internationally acknowledged fact. For example, Dr Stella Marega, University of Trieste, participated in a conference "Philosophy, Religion and Public Policy, at the University of Chester 2014”. She gave a presentation titled „Philosophy, Religion and Politics: Contributions and Perspectives of Politology of Religion”, where she said „I refer to a successful attempt done in the early ' 90 s, when two distinct schools laid the theoretical foundations of a new discipline: political science of religion, also called Politology of Religion or Politicology of Religion. In Eastern Europe, Miroljub Jevtic founded the Center for Study of Religion and Religious Tolerance at the University of Belgrade, Serbia, in 1993. In Germany, Claus E. Bärsch, (disciple of Eric Voegelin) gathered a group of scholars and researchers at Duisburg University, creating in 1996 the Institut für Religionspolitologie. Interesting contributions from this school were collected in 2005 in a volume programmatically entitled Wer Religion verkennt, erkennt Politik nicht: 'Who disregards religion does not know politics'”. A Similar statement was given by Nigerian colleagues in 2013 who said: "This possibly was why the political science of religion otherwise referred to as politicology or politology of religion was established in Serbia in 1993 before it became embraced in other parts of the world. The discipline was 
formally established as an academic one in the Faculty of Political Science of the University of Belgrade, Serbia, that year". The same thing can be found in the doctoral dissertation by Sergey S. Streljnikov titled "Mutual effects of political culture and confessional education in the condition of modernization in Russia", defended at Tyumen State University 2014. In his thesis he states the following: "Thinking about the influence of religion on contemporary political processes is done in the research of Serbian politologist M. Jevtic who is a founding father of politology of religion" [Streljnikov 2014: 8]. These above mentioned statements confirm that Politology of Religion was born in Belgrade at the Department of Political Science.

The biggest success of the Belgrade school of Politology of Religion, is the publication of the world's first journal in the English language in 2007. At this moment, there is one more journal of the same kind, published by APSA. However, this APSA Journal started publishing in 2008. The Politics and Religion Journal gathered so far hundreds of scholars from all over the world: as authors or as reviewers or as members of the editorial board and editorial board from abroad. Due to this fact, PRJ is one of the most international and most multicultural Journals in the world. In honor to the PRJ, numerous world famous universities organized scientific conferences. For example, two American Universities organized a conference in Florida in 2015. Similar conferences were organized in Argentina, Moscow, Beijing, Malesia etc.

If you search google using the term politology of religion in different languages: politology religion; politologie des religion; politologia della religione; politiologia de la religion; religionspolitologie; politologia religii in Polish, Russian: политологиярелигии or Arabic نبيدلاقسايسملع, you will find information which supports the above mentioned facts.

In conclusion, it should be mentioned that Politology of Religion already took its place in the world of political science. This conference in Warsaw is best proof for this. It is obvious that religion has massive influence on politics, making the education of political scientists without this course, incomplete and unable to produce quality students and professionals, capable of conducting adequate political analysis. As the German colleagues said "One who does not understand religion, cannot understand politics". In that sense, I understand this conference as a place for sharing a call to the ISPA and the ECPR to include Politology of Religion as a core course in the Political Science departments. Because it is more 
than clear that after the Introduction in political science, Politology of religion is the most important course for understanding politics and therefore, for the education of a political scientist.

\section{Bibliography:}

„A Bleak Outlook is Seen for Religion“, New York Times, 25.2.1968.

Berger P. (2008), Desekularizacija sveta-preporod religije i svetska politika, Novi Sad.

Dreyfus P. (1972), Du Pakistan au Bangladesh, Paris.

Krynicki-Krieger A. (1974), Le Paskistanetat des purs,Paris.

Kettell S. (2012), "Has Political Science Ignored Religion”,PS:PoliticalScience\&Politics, No. 1.

Lončar M. (2017), Osnove političkog delovanja Hizmet pokreta,Belgrade.

Jevtić M. (1974), Islamic understanding of war and the role of Islamic Conference in preserving peace, Belgrade.

Jevtic M. (2009), "Theoretical Relationship Between Religion and Politics", Indian Journal of Political Science, Vol. LXX, No. 2.

PetitLarousse (1961),Vol.11, Paris.

The World Almanac and book of fact (2016), New York. 